\title{
Webgis-based Irrigation basic Map Model of Merauke Regency Papua
}

\author{
Heru Ismanto \\ Information Engineering Dept. \\ Musamus University \\ Merauke Papua - Indonesia
}

\author{
Abner Doloksaribu \\ Civil Engineering Dept. \\ Musamus University \\ Merauke Papua - Indonesia
}

\author{
Andri Syafrianto \\ Information Engineering Dept. \\ STMIK El Rahma \\ Yogyakarta - Indonesia
}

\begin{abstract}
Irrigation network is channel, building, and its complementary building which is as a unity needed for provision, division, administration, usage, and disposal of irrigation water. The Public Works Water Resources Department which maintains the irrigation in Merauke Regency until recently has not have a Map of the Area for Irrigation by online which can be accessed by stakeholders of Local Government of Merauke Regency. The potential of Merauke Regency for agriculture is quite high [1], therefore to maintain the potential, it is needed a water resources maintenance, which functions as evaluation, monitoring, and operational, and maintenance of the irrigation network.

In this study, it will be conducted Web (WebGIS)-Based Geographical Information System Development by online in the Public Works Department of Merauke Regency. The method used in this development is SLDC/Water Fall (System Development Life Cycle). The objective of this study is to ease the Local Government of Merauke Regency through the Public Works Department in the maintenance of irrigation channels by online and integrated with the department dealing with Merauke regency. Data processing uses software ArcGIS and MapObject for the processing of the map, ArcGIS For Server, MS SQL Server for the making of database server, Apache for the making of web programs.
\end{abstract}

The result of this development of WebGIS is the irrigation maintenance can be done online by the Government of Merauke Regency which is maintain by the staff of Public Works Department of Merauke Regency. It also can be used by the decision makers in the irrigation maintenance in Merauke Regency.

\section{Keywords}

WebGIS, Water Fall, irrigation channels, Merauke Regency Papua.

\section{INTRODUCTION}

Agricultural land of Merauke Regency based on the data from Regional Planning and Development Agency of Merauke is 4,6 million Hectares and within a period of 5 years later it will be cultivated as much as 1,2 Hectares [1]. Of course, this matter will need equitable irrigation maintenance for agricultural needs in Merauke Regency, therefore, the irrigation maintenance needs to be done by the help of information technology that can ease the maintenance process. One of the technology that can help to expedite the maintenance process of irrigation system is by GIS (Geographic Information System) technology [2].

Along with the development of more advanced era, the development of technology also follows. The development of technology also influences to technological advances in the world of IT (Information Technology) which also develops rapidly. One of them is the presence of GIS (Geographic Information System) technology.

In this study, the researcher will develop Irrigation Basic Map Prototype Using Geographic Information System (GIS) in Merauke Regency, Papua Province which is based on Web (WebGIS, Online). WebGIS is an application of Geographic Information System (GIS) which can be accessed online through internet/web. On the configuration of WebGIS there is a server that functions as MapServer which has duty to process map request from the user/client and then send it back to the client. In this matter, the user/client does not need to have software of GIS, only uses internet browser such as Internet Explorer, Mozilla Fire Fox, or Google Chrome to access GIS information in the server.

\section{BASIC CONCEPT OF WEBGIS}

Geographic Information System (GIS) is a system which is designed to work with spatially referenced data or geography coordinates. GIS has ability to do the data processing and particular operations by showing and analyzing data. GIS application recently is increasing not only by number of application but also increasing from the variety types of its application. The development of the application in the future leads to Web-based application which is known by WebGIS [3]. This is because development of the application in network environment has shown great potential in relation with geo information[4][5].

\subsection{Architecture WebGIS}

To do communication with different components in web environment is needed a web server. Because the standard of geo data is various and very specific so the development of system architecture follows 'Client Server' architecture [6].

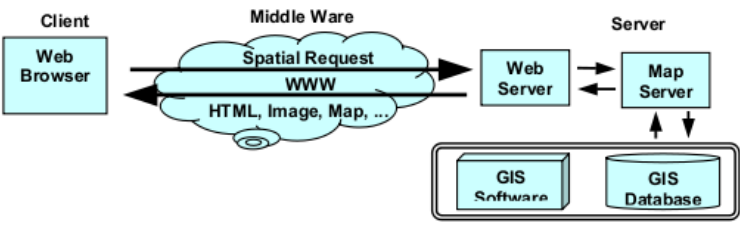

Figure 2.1. Architecture WebGIS

Figure 2.1 shows the minimum architecture of a WebGIS system. The application is in the side of the client that communicates with server as data provider through protocol web as HTTP (Hyper Text Transfer Protocol).

This kind of application can be developed using web browser (Mozzila Firefox, Opera, Internet Explorer, etc). To show and interact with GIS data, a browser needs Pug-In or Java Applet or even both. Web Server is responsible to process of requesting from the client and sending the reaction of the 
response. In architecture web, a web server also maintains communication by server side GIS component. It is then responsible to connection to spatial database such as translating query into SQL and making representation which is continued to server. In the fact, Side Server GIS Component is in the software libraries form which offers special service to spatial analysis on the data.

\subsection{Web GIS Service}

WebGIS-Based service has added an entirely new dimension where the GIS industry works. GIS web has made very easy to share spatial data through World Wide Web and can be accessed by every single user in rest of the world without having special GIS software loaded in its machine. WebGIS has potential to revolutionize way where GIS is developed, accessed, and used around the world.

WebGIS commonly uses 3-tier architecture, this makes possible to access attribute data together with spatial data through internet. This data can be integrated with more upcoming technologies such as GIS is integrated with Mobile Phone, GIS is integrated with CCTV.

WebGIS has helped to create platform of independent distribution channel for GIS data. The application can share data from different data sources and format and ask them to be combined in one application, without it, is being clear that data coming from different sources or location.

Desktop GIS has certain limitation. The user needs to have particular software and must be installed in the computer, be difficult to download data from many common platforms. These difficulties have been changed by webGIS, the data can be shared to around the world without having any particular software. Local government can publish data for the usage of society that needs the data. WebGIS plays the main role in the making of GIS technology affordable and useful for thousands of users in the real meaning.

\subsection{SDLC (Systems Development Life Cycle) / Water Fall}

Systems Development Life Cycle or commonly called Water Fall Method in the system engineering and software engineering, is a process of making and changing system also model and methodology which are used to developing the systems. This concept commonly refers to computer or information system. SDLC also a pattern taken for developing software system, which consists of many steps: planning, analysis, design, implementation, testing and maintenance. In the software engineering, SDLC concept underlies many kinds of software development methodology. These methodologies establish a framework for planning and controlling the making of information system, that is process of software development. There are 3 kinds of method of life cycle of the most used system, those are: traditional system life cycle, life cycle using prototyping, object-oriented system life cycle [7].

\section{WATER INFRASTRUCTURE}

Coming from an English words, water infrastructure has the meaning as channeling, draining, removing, and diverting water. In the civil engineering field, water infrastructure commonly can be defined as a technical action for reducing excess water, either that coming from rainwater, seepage, or irrigation water from an area or land, so that the function of land or areas is not disturbed. The water infrastructure can also be defined as an effort to control groundwater quality regarding to salinity. So, water infrastructure concerns not only surface water but also groundwater [8].

Generally, drainage system van be defined as water building series which functions to reduce and remove excess water from a land or area, so that the land can be functioned optimally. Traced from the headwater, the water infrastructure system building consists from interceptor drain, collector drain, conveyor drain, main drain, and receiving waters. Along the system, it is often found other buildings, such as culvert, siphon, aqueduct, spillway, sluice, building falls, an tando, pumping station. In the complete system, before entering into receiving water body, the water is processed first in the installation of wastewater treatment (IPAL), especially for mixed system. Only water that has met certain quality standards are inserted into receiving water bodies, so that it damages the environment.

The goals of building the channel infrastructure of urban water infrastructure, one of them is ensuring society's health and welfare; protecting the environment; avoiding danger, material damage, loss and other problems caused by overflow raging flood; improving environment quality; and conserving water resources.

[9] Did the study about Quantum GIS Open Source-Based Water Infrastructure Network Mapping in Makassar city. This research discussed water infrastructure mapping using Quantum GIS program. [10] Did the study about GIS Application to evaluate Water Infrastructure Network System in Sub-Watershed Lowokwaru, Malang city. The objective of the study is to evaluate the urban water infrastructure network system using GIS ArcView technology.

\section{RESEARCH METHODOLOGY}

The method used in this study is SLDC (System Development Life Cycle) method or often called Water Fall method which is started from planning to implementation. Data collecting is conducted by literature review and observation.

\section{a. Literature Review}

This method is used to obtain data and also theories supporting the study. It is also to learn books, published scientific researches, and understand literatures dealing with WebGIS discussion appropriate with this study.

b. Observation

Observation method is conducted by observing directly in the field to collect data about the irrigation in the Public Work Department of Merauke Regency. In this observation, the data obtained is spatial data and nonspatial data of tentative irrigation. The secondary data includes administrative boundary map, road network map, and water infrastructure network map. While the inventory survey includes survey of water infrastructure network system location, survey of sediment channel condition, survey of existing condition of water infrastructure channel structure.

\subsection{Developing System Method}

Developing WebGIS system is done by the following steps:

a. System Planning

Planning and describing the description of the system being made, planning the system based on the analysis result of the needs where the system will be developed based on WebGIS

b. System Making (Coding) of WebGIS Application 
Coding is done by system or WebGIS application making in accordance with the planning. Implementing the result of system planning becomes WebGIS software through programming language.

c. WebGIS Application System Testing

The system testing is done to test whether the ability of WebGIS application made in accordance with its planning, included the use of existing data analysis.

d. Evaluation and Improvement Implementation

On this level, WebGIS application being made is implemented in Public Work Department then evaluated the testing result also improved data analysis and the system being developed if there any mistakes.

e. Training

On this level, the training is conducted for the users from the WebGIS application being made so that the users can use this application as administrator users and non-administrator users.

\subsection{Flow Chart of WebGIS Making}

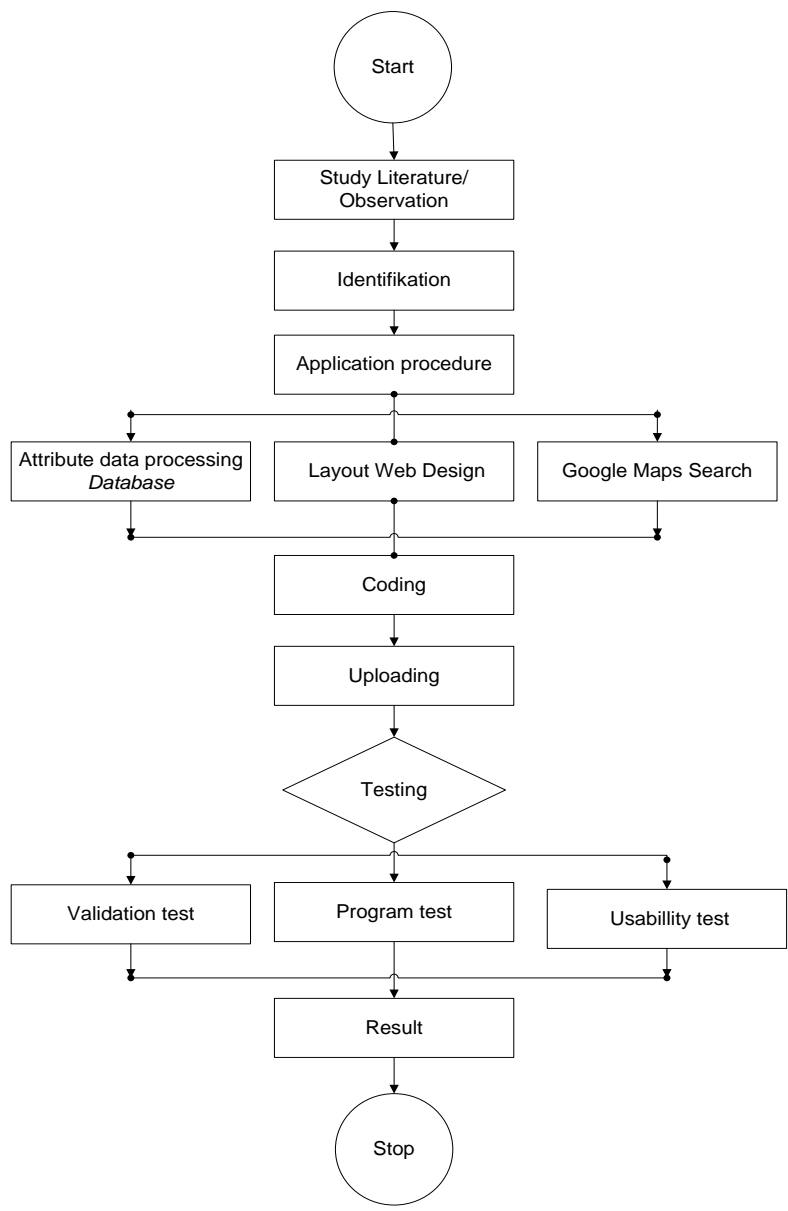

Figure 4.1. Flow Chart of WebGIS

\subsection{System Testing}

The system application testing is done using questionnaire method. The questionnaire is given to the system users those are 10 (ten) Local Government employees of Merauke Regency.
After the users operating the system then they are given ten questions in questionnaire form to be answered related to the system application they operated.

\section{DISCUSSION}

From the result of system testing to the users or respondents, which the users are the Local Government employees in number of ten, so it is obtained the result of testing as in the table 5.1 chart 5.1 and chart 5.2

Table 5.1 Result of Respondent

\begin{tabular}{|c|c|c|c|c|c|}
\hline $\begin{array}{c}\text { Ques } \\
\text { Tion }\end{array}$ & $\begin{array}{c}\text { Very } \\
\text { good }\end{array}$ & good & Sufficient & less & worst \\
\hline $\mathbf{1}$ & 3 & 4 & 2 & 1 & 0 \\
\hline $\mathbf{2}$ & 2 & 2 & 4 & 1 & 1 \\
\hline $\mathbf{3}$ & 2 & 3 & 2 & 2 & 1 \\
\hline $\mathbf{4}$ & 4 & 3 & 2 & 1 & 0 \\
\hline $\mathbf{5}$ & 4 & 2 & 3 & 0 & 1 \\
\hline $\mathbf{6}$ & 4 & 3 & 2 & 0 & 1 \\
\hline $\mathbf{7}$ & 5 & 3 & 2 & 0 & 0 \\
\hline $\mathbf{8}$ & 5 & 4 & 1 & 0 & 0 \\
\hline $\mathbf{9}$ & 4 & 4 & 2 & 0 & 0 \\
\hline $\mathbf{1 0}$ & 1 & 2 & 5 & 2 & 0 \\
\hline
\end{tabular}

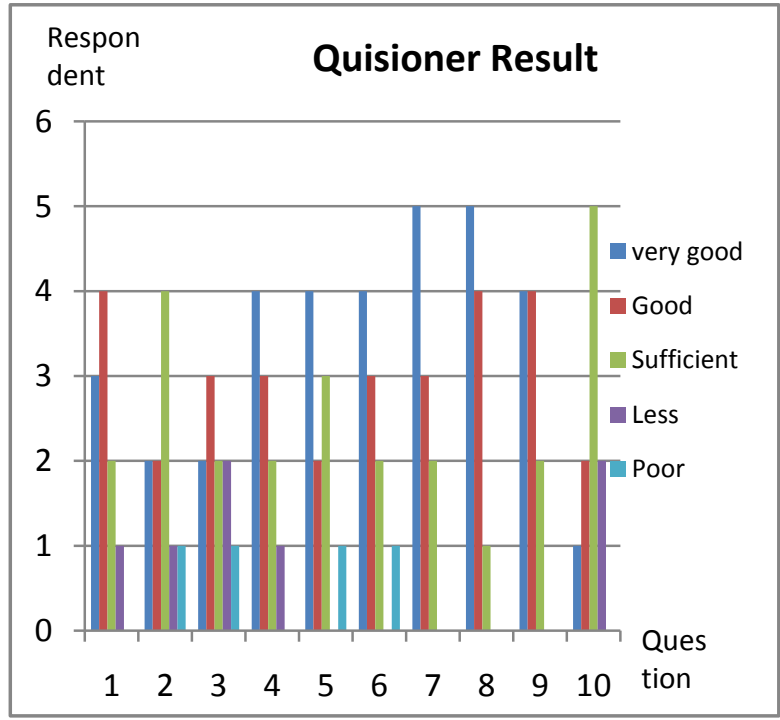

\section{Chart 5.1. Result of Questionnaire}

From the chart 5.1, it can be seen the difference of respondents' answers from very good, good, sufficient, less and worst.

Total of each answer can be seen in the chart 5.2. 


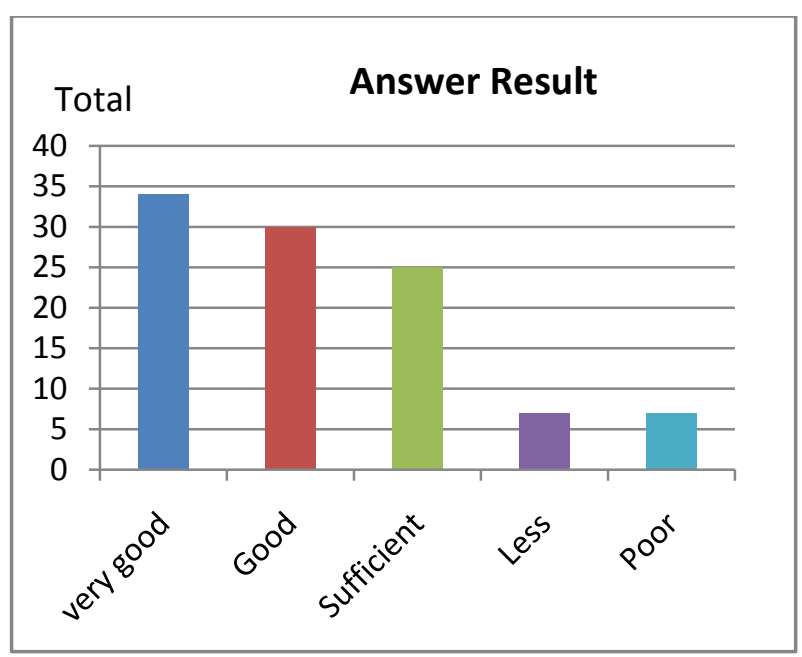

Chart 5.2. Total of Answer

\section{CONCLUSION}

After the researchers doing the research, so they can take some conclusions, as follows:

a. Application of irrigation basic map prototype development system which is made using GIS can show the irrigation maintenance completely in Merauke Regency such as showing map of administrative area, map of irrigation channel, map of primary sluice, map of secondary sluice, map of flood dike, map of village, and good roadmap, those are shown in the result of respondents' questionnaire in the discussion.

b. The report which is resulted by the application of irrigation basic map prototype development system through attribute data for every map based on the data in the field and dynamic, changeable as updating of map data.

c. The right to access updating the data on this system is owned by the administrator.

\section{ACKNOWLEDGMENTS}

Thanks to the Ministry of Research Technology And Higher Education of Indonesian Government has support researchers in developing research model.

\section{REFERENCES}

[1] Bappeda Kab. Merauke, 2012, “ Merauke Dalam Angka “, BPS Kab. Merauke, CV. Sekar Wangi, Merauke.

[2] Prahasta, E, 2001, "Konsep-Konsep Dasar Sistem Informasi Geografis”, Informatika, Bandung.

[3] Charter, Denny. Agtrisari, Irma. 2002. " Desain dan Aplikasi GIS Geographics Information System”, PT. Elex Media Komputindo, Jakarta.

[4] Radjabidfard, Abbas, 2001, “ SDI Hierarchy, from Local to Global SDI Initiatives", Melbourne, Victoria: Spatial Data Research Group, Departement of Geomatics. The University of Melbourne.

[5] Prahasta, E., 2007,"Sistem Informasi Geografis: Membangun Aplikasi WebBased GIS dengan MapServer", Informatika, Bandung

[6] Budi Santoso, (2011), "Pengembangan Perangkat Lunak Sistem Informasi Geografis Berbasis Web", Jurnal Telematika Vol 7 No. 3, Hal 119-128.

[7] Blanchard, B. S., \& Fabrycky, W. J., (2006), “ Systems engineering and analysis (4th ed.)", New Jersey, Prentice Hall.

[8] Sidharta, 1997, “ Irigasi dan Bangunan Air " Gunadarma, Jakarta.

[9] Rauf, S., 2012,"Pemetaan Jaringan Prasarana pengairan Berbasis Quantum GIS Open Source di Kota Makasar", Prosiding Hasil Penelitian Fakultas Teknik Unhas, Makassar.

[10] Rachmawati, A., 2007,“Aplikasi SIG (Sistem Informasi Geografis) untuk Evaluasi Sistem Jaringan Prasarana pengairan di Sub DAS Lowokwaru Kota Malang", Jurnal Rekayasa Sipil, Jurusan Teknik Sipil, Fakultas Teknik, Universitas Islam Malang. 